\title{
Effect of Environmental Pollution on Leafe Composition, Fruit Set and Fruit Quality of Hayany Date Palm
}

\author{
Hoda S. H. Aly and Adel A. Abou El-Soad 1
}

\begin{abstract}
The present study was carried out during two successive seasons 2006 and 2007, on Hayany date palm cultivar grown at four locations differed in environmental pollution in Alexandria Governorate. (A) Mostafa Kamel street as indicated to manufacturing and high way area, (B) Air port road as a density of settlement and traffic area, (C) El-Montaza Garden as a high density of plants and vehicular traffic and (D) El-Mamoura Botanical Garden (Horticulture Research Institute) as a palm trees orchard, fare from the major road about $\mathbf{7 0 0}$ meters. The effect of environmental pollution on pinnae composition, fruit set and fruit quality was studied. Soil analysis for every location were taken at two depths $0-30 \mathrm{~cm}$ and 30-60 cm to determine some heavy metals $(\mathrm{Cd}$ and $\mathrm{Pb})$ content. Regarding the yield, highest yield was obtained at locations (C) and (D), while it was the lowest at, locations (A) and (B). Fruit set percentage was lowest at location (B) in comparison with other tested regions. Concerning physical properties, significant differences in fruit dimension, weight and flesh/fruit weight percentage they showed greater values at location (D) and lower at location (B). As for chemical properties, total sugars content was significantly higher in fruits at location (C), whereas it was the lowest at location (D), such differences were significant. Regarding T.S.S\%, the differences between tested locations did not reach the level of significant. Fruits of "Hayany" had lower tannins percentage at location (A) as compared with other locations; no significant differences were detected in this respect between other three tested locations. Concerning effect of environmental pollution on some minerals content in fruits and pinnae, nitrogen, potassium and lead content in fruits increased in location (A) than other locations. Phosphorus content was significantly higher at location (D), whereas, it was the lowest at location (B). Cadmium content was not found in fruits or pinnae among all tested locations. As for pinnae mineral content, at location (C); nitrogen was the lowest, whereas phosphorus was the highest in comparison with other tested locations. Regarding potassium content, it gave highest value at location (D) than other locations. No significant differences were detected in pinnae lead content among tested locations. The results of this study emphasize that Hayany date palm cultivar was not affected by pollution contamination.
\end{abstract}

\section{INTRODUCTION}

\footnotetext{
${ }^{1}$ Department of Tropical Fruit, Horticulture Research Institute, Agriculture Research Center, Egypt.

E-mail:hoda_saad23@yahoo.com

Received Febuary8, 2009, Accepted Febuary25, 2009
}

Date palm (Phoenix dactylifera L.) is one of the important fruit species grown in Egypt. The climate of Egypt favors the growth of palm trees which may be considered as the most ancient trees in the country (Bircher, 1990). It can grow well under drastic environmental conditions which may be not suitable for many fruit species. It can grow in extreme arid areas to produce many useful products (Wafaa, Amer and Zahran 1999). Most of the dozen or more species of the genus Phoenix are grown as ornamental palms indoors or out. Only the common date, P. dactylifera L., is cultivated for its fruit. Often called the edible date, it has few alternate names except in regional dialects. Date palm tree is one of beautiful trees so, now is planted in most of Alexandria streets and pollinated to produce fruits

The fruit tree near the factories, highway and other contamination sources were subjected to different injuries especially those subjected to heavy metals pollution, Lagenwerrff and Specht (1970) reported that the concentration of $\mathrm{Cd}, \mathrm{Ni}, \mathrm{Pb}$ and $\mathrm{Zn}$ in road side soil and grass samples from several locations decreased with the distance from vehicular traffic. Concentration was related to the composition of gasoline, motor oil, and automobile tires and to roadside deposition of residues of these materials concentration from motor vehicle emissions with in $100 \mathrm{~m}$ from the roadway has been reported in vegetation (Motto et al., 1970; Ward et al., 1975; Yassoglou et al., 1987 and Hose et al., 2002)

Likewise, the increasing of such heavy metals might affect the human health especially when these metals were found in high levels in the edible parts of the fruit (Favretto et al., 1975; Serra et al., 1981; Pavan and Bingham, 1982 and Rupp et al., 1985). Date palm leaves are suitable as a biomonitor for atmospheric heavy metal-polluted traffic (Divrikli, et al., 2006)

The harmful effect of dust pollution on growth and productivity of plants was reported by many investigators, Iren and Katiricioglu (1984) reported that a dust covering reduced transpiration, prevented photosynthesis and amounts of chlorophyll of apples.

Field experiments included sampling of leaves from mature trees in areas with different air pollution load 
(passive monitoring), exposure of samplings cultivated in uniform soil at these areas (active monitoring) and a study on the combined effects of contaminated soil and air pollution. Growth analysis of exposed saplings demonstrated that a change of the relationship between above-ground and below-ground plant parts was the most obvious effect of air pollution and soil contamination. (Klumpp et al., 2000).

The leaves of Populus nigra L. (Salicaceae), which are used as biomonitor to investigate the levels of the trace elements $\mathrm{Cd}, \mathrm{Pb}, \mathrm{Fe}, \mathrm{Zn}$ and $\mathrm{Cu}$, were sampled at 30 locations having different pollution levels in the regions. The samples were collected at both reference and contaminated locations where iron was found as the priority element. The strong association between a gradient of contamination and concentration in all samples tested indicates that they are reflecting well the environmental changes, and that they appear as appropriate biological indicators of heavy metal contamination (Baslar et al., 2005).

Present investigation was carried out to study the effect of street pollution on yield and fruit characteristics and to determine of some heavy metals $(\mathrm{Pb}$ and $\mathrm{Cd})$ in fruits and pinnae, for "Hayany" date palm cultivar growing on Alexandria streets.

\section{MATERIALS AND METHODS}

The present investigation was carried out during 2006 and 2007 seasons, on "Hayany" date palms grown at four different locations in Alexandria governorate. The first one was located in Mostafa Kamel street as indicated to manufacturing and high way area (A), second location Air port road as a density of settlement and traffic area (B), third one El-Montaza Garden as a high density of plants and vehicular traffic (C) and fourth El-Mamoura Botanical Garden (Horticulture Research Institute) as a palm trees orchard, far from the major road about 700 meters (D). All palms received

Table 1. Soil analysis for the different locations of some chemical characteristics of the experiment

\begin{tabular}{|c|c|c|c|c|c|c|c|}
\hline Depth & $\mathbf{p H}$ & $\begin{array}{l}\text { EC } \\
\text { mmhos/cm }\end{array}$ & $\begin{array}{l}\mathrm{Na}^{+} \\
\mathrm{meq} / \mathrm{L}\end{array}$ & $\begin{array}{l}\mathrm{Ca}^{++} \\
\mathrm{meq} / \mathrm{L}\end{array}$ & $\begin{array}{l}\mathrm{Mg}^{++} \\
\mathrm{meq} / \mathrm{L}\end{array}$ & $\begin{array}{l}\text { K } \\
\text { meq/L }\end{array}$ & $\begin{array}{l}\mathrm{Cl}^{-} \\
\mathrm{meq} / \mathrm{L}\end{array}$ \\
\hline & \multicolumn{7}{|c|}{ Moustafa Kamel (A) } \\
\hline $0-30 \mathrm{Cm}$ & 8.10 & 1.33 & 1.98 & 2.5 & 5.0 & 0.31 & 2.5 \\
\hline \multirow[t]{2}{*}{$30-60 \mathrm{Cm}$} & 8.22 & 0.86 & 1.25 & 2.0 & 4.5 & 0.19 & 1.1 \\
\hline & \multicolumn{7}{|c|}{ Air port road (B) } \\
\hline $0-30 \mathrm{Cm}$ & 7.89 & 1.92 & 0.87 & 1.97 & 2.03 & 0.31 & 3.12 \\
\hline \multirow[t]{2}{*}{$30-60 \mathrm{Cm}$} & 7.82 & 1.63 & 0.53 & 1.41 & 1.67 & 0.24 & 2.34 \\
\hline & \multicolumn{7}{|c|}{ El-Montaza Garden (C) } \\
\hline $0-30 \mathrm{Cm}$ & 7.88 & 0.73 & 2.81 & 3.0 & 1.0 & 0.224 & 4.0 \\
\hline \multirow[t]{2}{*}{$30-60 \mathrm{Cm}$} & 7.90 & 0.41 & 1.13 & 1.6 & 0.6 & 0.159 & 1.5 \\
\hline & \multicolumn{7}{|c|}{ El-Mamoura Botanical Garden (D) } \\
\hline $0-30 \quad \mathrm{Cm}$ & 7.89 & 0.86 & 0.72 & 2.86 & 1.89 & 0.69 & 4.0 \\
\hline $30-60 \mathrm{Cm}$ & 7.78 & 0.65 & 0.46 & 1.31 & 1.94 & 0.26 & 1.5 \\
\hline
\end{tabular}

similar cultural practices do not received any fertilizers through this investigation, all selected palms were pruned at level maintaining all palms have the same number of functional leaves. Five palms at every location of nearly the same age (18 years old) were chosen. Pollen grains from the same male palm were used for pollination in both seasons.

Soil samples were collected from 0-30 cm and 30$60 \mathrm{~cm}$ from soil surface to study chemical characteristics including soil $\mathrm{pH}$, total soluble salts (EC) and available soil nutrients $(\mathrm{K}, \mathrm{Mg}$ and $\mathrm{Ca}$ ) which were determined as illustrated by Carter (1993), the analysis is presented in Table (1). Some heavy metals were determined, the concentration of total $\mathrm{Cd}$ and $\mathrm{Pb}$ in soils were determined by wet digestion with aqua regia solution (Black, 1965) and the data are presented in Tables (1 and 2). The following indices were studied and recorded: Yield per palm was determined at harvest date. Twenty strands per bunch from each experimental palm were used to determine fruit set percentage and fruit retention percentage which calculated as the following equation:

Fruit set $\%=$ (Number of fruit set/Number of flowers) $\times 100$

Fruit retention $\%=($ Number of fruits at harvest/Number of fruit set) $\times 100$

Physical and chemical characteristics of fruits: representative fruit sample 30 fruits were collected at full color stage (Khlal stage) in the mid of October to determine weight of fruit, pulp and seed as (gm), fruit dimensions, flesh thickness and flesh/seed ratio was calculated. Total Soluble Solids (T.S.S.) was determined using a hand referactometer and the total sugars were determined according to Dubios et al., (1956). Tannins content were determined according to Swain and Hillis (1959). 
Fruit and Pinnae minerals content: Fruit and pinnae samples (20 pinnae from each experimental palm were collected at mid November of 2006 and 2007 seasons from the medium part of the five consecutive leaves which less than one year old and located just over the fruiting zone as described by Rizk, 1987) were washed, then dried at $70^{\circ} \mathrm{C}$ ground and wet digested using $\mathrm{H}_{2} \mathrm{SO}_{4}$ and $\mathrm{H}_{2} \mathrm{O}_{2}$ (Evenhuis and Dewaard, 1980). Suitable aliquots were then taken to determine the following elements: Total nitrogen and phosphorus were determined calorimetrically according to Evenhuis (1976) and Murphy and Riley (1962), respectively. Potassium was determined by Pertracourt PEP1 Flame Photometer. Lead and Cadmium were determined by Perkin Elmer Atomic Absorption Sepctrophotometer Model 305 B. The obtained data were statistically analyzed according to Sendecor and Cochran (1990) and LSD test at 0.05 levels were used for comparison between palms on each location.

\section{RESULTS AND DISCUSSIONS}

\section{Soil analysis:}

The data presented in Table (2) showed that concentration levels of total lead ranged in soil from 1.974 to $9.684 \mu \mathrm{g} / \mathrm{gm}$ at different locations and the highest value accumulation in soil appear at location (B) (air port road) than those of other locations. This finding was low than found by Yetimoglu et al. (2007) in Istanbul $368.3 \mu \mathrm{g} / \mathrm{gm}$ which may be due to the different soil $\mathrm{pH}$ between Egypt and Istanbul. The average value of cadmium ranged from 0.044 to 0.126 $\mu \mathrm{g} / \mathrm{gm}$. This value is close to the background level of total $\mathrm{Cd}$ in normal unpolluted soils as reported by Shalaby et al., (1999) in their studies of soils of Abu Qir region which was $0.2 \mathrm{ppm}$. However, Kabata-Pendias and Pendias (1992) reported that the worldwide mean of total $\mathrm{Cd}$ in the surface soil layer is $0.53 \mathrm{ppm}$ and that all higher values reflect the anthropogenic impact of $\mathrm{Cd}$ in soils.

Table 3. Effect of different locations on yield $(\mathrm{kg} / \mathrm{palm})$, retention of fruits and fruit set percentages for "Hayany" date palm cultivar in 2006 and 2007 seasons

\begin{tabular}{|c|c|c|c|c|c|c|}
\hline \multirow[t]{2}{*}{ Location } & \multicolumn{2}{|c|}{$\begin{array}{c}\text { Yield } \\
\text { (Kg/palm) }\end{array}$} & \multicolumn{2}{|c|}{$\begin{array}{c}\text { Retention fruits } \\
\text { percentage }\end{array}$} & \multicolumn{2}{|c|}{$\begin{array}{c}\text { Fruit set } \\
\text { percentage } \\
\end{array}$} \\
\hline & 2006 & 2007 & 2006 & 2007 & 2006 & 2007 \\
\hline A & $23.33 b$ & $32.77 \mathrm{c}$ & $36.42 \mathrm{a}$ & $35.33 \mathrm{a}$ & $75.56 \mathrm{a}$ & 70.27ab \\
\hline B & $24.97 \mathrm{~b}$ & $25.53 \mathrm{c}$ & $20.04 \mathrm{~b}$ & $24.82 b$ & $66.14 \mathrm{~b}$ & $63.82 \mathrm{~b}$ \\
\hline $\mathrm{C}$ & $71.83 \mathrm{a}$ & $79.40 \mathrm{a}$ & $35.57 \mathrm{a}$ & $36.45 \mathrm{a}$ & $75.67 \mathrm{a}$ & $71.15 \mathrm{ab}$ \\
\hline $\mathrm{D}$ & $66.97 \mathrm{a}$ & $69.60 \mathrm{~b}$ & $38.89 \mathrm{a}$ & $40.20 \mathrm{a}$ & $79.53 \mathrm{a}$ & $73.84 a$ \\
\hline
\end{tabular}

Values with the same letter(s) in each column are not significantly differed at 0.05 level
Table 2. Concentration of total lead and cadmium in effective soil depth and locations of study

\begin{tabular}{|c|c|c|}
\hline \multirow[t]{2}{*}{ Depth } & Pb $\mu g / g m$ & $\mathrm{Cd} \mu \mathrm{g} / \mathrm{gm}$ \\
\hline & \multicolumn{2}{|c|}{ Moustafa Kamel (A) } \\
\hline $0-30 \quad \mathrm{Cm}$ & 4.056 & 0.050 \\
\hline $30-60 \mathrm{Cm}$ & 4.944 & 0.044 \\
\hline & \multicolumn{2}{|c|}{ Air port Road (B) } \\
\hline $0-30 \quad \mathrm{Cm}$ & 7.122 & 0.126 \\
\hline $30-60 \mathrm{Cm}$ & 9.684 & 0.048 \\
\hline & \multicolumn{2}{|c|}{ El-Montaza Garden $(\mathrm{C})$} \\
\hline $0-30 \quad \mathrm{Cm}$ & 1.974 & 0.048 \\
\hline $30-60 \mathrm{Cm}$ & 4.416 & 0.058 \\
\hline & \multicolumn{2}{|c|}{ El-Mamoura Botanical Garden (D) } \\
\hline $0-30 \quad \mathrm{Cm}$ & 1.992 & 0.600 \\
\hline $30-60 \mathrm{Cm}$ & 3.396 & 0.560 \\
\hline
\end{tabular}

\section{Yield and fruit setting:}

The results of two experimental seasons, Table (3) showed that yield per palm was significantly higher at location (C) and (D) in the first season and location (C) in the second season, whereas location (A) and (B) were lowest percentage in both seasons. As for fruit retention percentage, location (B) had a significant lowest value comparing with all other locations in both seasons. Concerning the fruit set percentage, location (D) gave the highest percentage than the value recorded in location (B) and the differences were statistically significant, while the differences between locations (A) and (C) did not reach the level of significance. These were true in the first season only, but in the second location (B) given the lowest percentage and the differences were statistically significant between this location and all the others. These findings might be due to the dust and heavy metals contamination which affect of flower content for the number of strands. Kawamata and Miyakoda (1973), however, found that no abnormally was found in flowering and fruiting of any studied fruit tree; chestnut, grape, peach and plum with cadmium. 


\section{Fruit physical properties:}

The data presented in Table (4) indicated that in both seasons fruit weight significantly higher for palm trees planted in location (D) and the lower significant value at location (B). Whereas, location (D) gave higher flesh weight in both seasons. In regard to seed weight the obtained data show that there are no consistent trends in seed weight between different locations. This was true in both seasons. These findings are agreed with those found by Haggag and El-Kobbia (1989). They found that the trees adjacent the road 5 and 25 meters from motorway had significantly lower fruit weight as compared with those distant from the road. Concerning the fruit dimensions (fruit length, diameter and flesh thickness), the data also showed that fruit dimensions, flesh thickness and flesh/seed ratio were significantly higher at locations (C) and (D) in both seasons. These findings disagreed with those obtained by Haggag and El-Kobbia (1989), they found the fruit peel thickness was not significantly affected by distances from the road.

\section{b- Fruit chemical properties:}

The data representing the contamination effects on the total sugars, total tannins and total soluble solids are listed in (Table 5). The results revealed that, fruit total sugars content were significantly higher in fruits locations (B) and (C) in the first season and location (C) in the second one. Regarding fruit tannins content, in both seasons, fruit tannins content were significantly lower at location (A) as compared with other locations, no significant differences were detected in this respect between other three tested locations. Total soluble solids were not affected in all locations for both seasons. These results are agreement with those obtained by Manago et al., (1974) and Haggag and ElKobbia (1989).

Table 4. Effect of different locations on some physical characteristics for"Hayany"date palm cultivar in 2006 and 2007 seasons

\begin{tabular}{|c|c|c|c|c|c|c|c|}
\hline Location & $\begin{array}{c}\text { Fruit } \\
\text { weight } \\
\text { (gm) }\end{array}$ & $\begin{array}{c}\text { Flesh } \\
\text { weight } \\
\text { (gm) }\end{array}$ & $\begin{array}{c}\begin{array}{c}\text { Seed } \\
\text { weight } \\
(\mathrm{gm})\end{array} \\
\end{array}$ & $\begin{array}{c}\text { Fruit } \\
\text { diameter } \\
(\mathbf{c m})\end{array}$ & $\begin{array}{c}\text { Fruit } \\
\text { length } \\
\text { (cm) }\end{array}$ & $\begin{array}{c}\text { Flesh } \\
\text { thickness } \\
(\mathrm{cm})\end{array}$ & $\begin{array}{c}\text { Flesh } / \text { seed } \\
\text { ratio }\end{array}$ \\
\hline \multicolumn{8}{|c|}{2006} \\
\hline A & $21.21 \mathrm{~b}$ & $18.13 b$ & $3.08 \mathrm{a}$ & $2.47 \mathrm{~b}$ & $4.93 b$ & $0.68 b c$ & $67.63 \mathrm{c}$ \\
\hline B & $17.18 \mathrm{c}$ & $15.50 \mathrm{~b}$ & $2.13 b$ & $2.20 \mathrm{c}$ & $4.90 \mathrm{~b}$ & $0.60 \mathrm{c}$ & $69.39 \mathrm{~b}$ \\
\hline $\mathrm{C}$ & $23.69 b$ & $21.39 \mathrm{a}$ & $2.30 \mathrm{~b}$ & $2.75 \mathrm{a}$ & $5.63 a$ & $0.81 \mathrm{a}$ & $71.86 \mathrm{a}$ \\
\hline D & $27.16 \mathrm{a}$ & $24.33 \mathrm{a}$ & $2.83 a$ & $2.65 \mathrm{a}$ & $5.43 \mathrm{a}$ & $0.78 \mathrm{ab}$ & $71.16 \mathrm{a}$ \\
\hline \multicolumn{8}{|c|}{2007} \\
\hline A & $20.74 \mathrm{c}$ & $17.72 \mathrm{c}$ & $3.02 \mathrm{a}$ & $2.49 b$ & $4.87 \mathrm{~b}$ & $0.67 \mathrm{~b}$ & $67.61 \mathrm{~b}$ \\
\hline B & $18.63 \mathrm{~d}$ & $16.11 \mathrm{c}$ & $2.52 \mathrm{~b}$ & $2.31 \mathrm{c}$ & $4.84 \mathrm{~b}$ & $0.61 \mathrm{~b}$ & $68.49 b$ \\
\hline $\mathrm{C}$ & $24.74 b$ & $22.09 \mathrm{~b}$ & $2.65 \mathrm{~b}$ & $2.68 \mathrm{a}$ & $5.66 \mathrm{a}$ & $0.81 \mathrm{a}$ & $70.96 a$ \\
\hline D & $27.72 \mathrm{a}$ & $24.80 \mathrm{a}$ & $2.92 \mathrm{a}$ & $2.60 \mathrm{ab}$ & $5.59 \mathrm{a}$ & $0.79 a$ & $71.08 \mathrm{a}$ \\
\hline
\end{tabular}

\section{Fruit and pinnae minerals content:}

Concerning effect of different locations on some minerals content in fruit and pinnae the data listed in Table (6) showed that in the two seasons, fruit nitrogen, potassium and lead content significantly increased at location (A) than that of other locations. Hoda, Aly (2003) showed that Samany fruits contained a significant higher concentration of lead ranged from 1.01 to $1.03 \mathrm{ppm})$ than that in Zaghloul fruits (0.86 to $0.97 \mathrm{ppm}$ ), this means that Samany cultivar; accumulates more lead in fruits than Zaghloul cultivar. Cadmium is present at low concentrations in with those that are consumed in larger quantities marking the greatest contributions to the population dietary exposure of $0.012 \mathrm{mg} / \mathrm{kg}$ (Ysart et al., 2000). Radwan and Salama (2006) showed that the level of $\mathrm{Pb}$ in all commodities were between $0.01 \mathrm{mg} / \mathrm{Kg}$ in potatoes and $0.87 \mathrm{mg} / \mathrm{Kg}$ in strawberries, also, they reported that within the selected fruits, the highest concentrations of $\mathrm{Pb}$ were noticed in strawberries followed by peach melon and date. Whereas, phosphorus content was statistically significant for location (D) in the second season, but in the first season the significante appear between location (D) and locations (A) and (B). Cadmium content has not found in fruits among all tested locations. Hoda, Aly (2003) showed that cadmium content in Zaghloul and Samany fruits were $0.009 \mathrm{ppm}$ in both seasons of study. Li et al., (2005) found that cadmium content in fruits for different trees were $2.15 \mathrm{mg} / \mathrm{kg}$ dry weight.

As for pinnae minerals content the data in the same table showed that nitrogen content in pinnae was decreased in location (C) and the differences were statistically significant between location (B) only in the first season, whereas, in the second season the significance appears among location (D) and all other 
Values with the same letter(s) in each column are not significantly differed at 0.05 level

Table 5. Effect of different locations on some chemical characteristics (\%on fresh weight basis) for "Hayany"date palm cultivar in 2006 and 2007 seasons

\begin{tabular}{ccccccc}
\hline \multirow{2}{*}{ Location } & \multicolumn{2}{c}{ Total sugars \% } & \multicolumn{2}{c}{ Total tannins \% } & \multicolumn{2}{c}{ T.S.S. \% } \\
\cline { 2 - 7 } & $\mathbf{2 0 0 6}$ & $\mathbf{2 0 0 7}$ & $\mathbf{2 0 0 6}$ & $\mathbf{2 0 0 7}$ & $\mathbf{2 0 0 6}$ & $\mathbf{2 0 0 7}$ \\
\hline A & $57.50 \mathrm{~b}$ & $57.63 \mathrm{c}$ & $1.65 \mathrm{~b}$ & $1.60 \mathrm{~b}$ & 30.39 & 30.40 \\
B & $64.15 \mathrm{a}$ & $64.36 \mathrm{~b}$ & $2.11 \mathrm{a}$ & $2.13 \mathrm{a}$ & 32.00 & 31.50 \\
C & $67.04 \mathrm{a}$ & $68.63 \mathrm{a}$ & $2.32 \mathrm{a}$ & $2.26 \mathrm{a}$ & 30.83 & 31.50 \\
D & $51.67 \mathrm{c}$ & $56.10 \mathrm{c}$ & $2.33 \mathrm{a}$ & $2.31 \mathrm{a}$ & 31.22 & 31.17 \\
\hline
\end{tabular}

Values with the same letter(s) in each column are not significantly differed at 0.05 level

Table 6. Effect of different locations on Nitrogen, Phosphorus, Potassium and lead (on dry weight basis) on fruits and pinnae "Hayany" date palm cultivar in 2006 and 2007 seasons

\begin{tabular}{|c|c|c|c|c|c|c|c|c|c|c|}
\hline & \multicolumn{2}{|c|}{$\mathbf{N}(\%)$} & \multicolumn{2}{|c|}{$\mathbf{P}(\%)$} & \multicolumn{2}{|c|}{$\mathrm{K}(\%)$} & \multicolumn{2}{|c|}{ Pb (ppm) } & \multicolumn{2}{|c|}{ Cd (ppm) } \\
\hline & 2006 & 2007 & 2006 & 2007 & 2006 & 2007 & 2006 & 2007 & 2006 & 2007 \\
\hline & \multicolumn{10}{|c|}{ Fruit } \\
\hline A & $2.63 \mathrm{a}$ & $2.57 \mathrm{a}$ & $0.39 b c$ & $0.39 \mathrm{c}$ & $2.07 \mathrm{a}$ & $1.90 \mathrm{a}$ & $1.008 \mathrm{a}$ & $1.023 \mathrm{a}$ & 0.00 & 0.00 \\
\hline B & $2.27 \mathrm{~b}$ & $2.23 \mathrm{~b}$ & $0.36 c$ & $0.36 \mathrm{~d}$ & $1.37 \mathrm{~b}$ & $1.23 \mathrm{c}$ & $0.605 b$ & $0.613 b$ & 0.00 & 0.00 \\
\hline $\mathrm{C}$ & $2.20 \mathrm{c}$ & $2.13 \mathrm{~b}$ & $0.41 \mathrm{ab}$ & $0.40 \mathrm{~b}$ & $1.47 \mathrm{~b}$ & $1.43 \mathrm{~b}$ & $0.638 \mathrm{ab}$ & $0.590 \mathrm{~b}$ & 0.00 & 0.00 \\
\hline \multirow[t]{2}{*}{$\mathrm{D}$} & $1.97 \mathrm{~d}$ & $1.90 \mathrm{c}$ & $0.44 \mathrm{a}$ & $0.44 \mathrm{a}$ & $1.50 \mathrm{~b}$ & $1.40 \mathrm{~b}$ & $0.581 \mathrm{~b}$ & $0.527 \mathrm{~b}$ & 0.00 & 0.00 \\
\hline & \multicolumn{10}{|c|}{ Pinnae } \\
\hline A & $2.53 \mathrm{ab}$ & $2.67 \mathrm{a}$ & $0.34 \mathrm{~b}$ & $0.33 \mathrm{~d}$ & $0.79 \mathrm{ab}$ & $0.70 \mathrm{c}$ & $0.652 \mathrm{a}$ & $0.650 \mathrm{a}$ & 0.00 & 0.00 \\
\hline B & $2.93 \mathrm{a}$ & $2.77 \mathrm{a}$ & $0.42 \mathrm{ab}$ & $0.40 \mathrm{~b}$ & $0.72 b$ & $0.73 c$ & $0.660 \mathrm{a}$ & $0.677 \mathrm{a}$ & 0.00 & 0.00 \\
\hline $\mathrm{C}$ & $2.33 b$ & $2.23 \mathrm{~b}$ & $0.46 \mathrm{a}$ & $0.45 a$ & $0.84 \mathrm{ab}$ & $0.86 b$ & $0.742 \mathrm{a}$ & $0.713 \mathrm{a}$ & 0.00 & 0.00 \\
\hline $\mathrm{D}$ & $2.73 \mathrm{ab}$ & $2.77 \mathrm{a}$ & $0.43 \mathrm{a}$ & $0.39 \mathrm{c}$ & $0.95 \mathrm{a}$ & $0.93 \mathrm{a}$ & $0.868 \mathrm{a}$ & $0.703 \mathrm{a}$ & 0.00 & 0.00 \\
\hline
\end{tabular}

Values with the same letter(s) in each column are not significantly differed at 0.05 level

locations. The lowest value for nitrogen content in pinnae for location (C) in both seasons may be due to this location covered with couch grass and those plants consume of some soil nitrogen. Regarding phosphorus content in pinnae, the data showed that location (C) has highest value in two seasons and the differences were statistically significant between all locations in the second season only. As for potassium content in pinnae, the data showed that location (D) had highest value in two seasons and the differences were statistically significant between all locations in the second season only. Concerning the lead content in pinnae, the data showed no significant differences appear among all tested locations in both seasons. It could be due to the absorbed selectivity of date palm or to $\mathrm{pH}$ in the examined soil or the pinnae and fruits covered with waxes and cuticle to keep from polluted air to reach inside the tissue. Cadmium content was not found in pinnae among all tested locations.

\section{CONCLUSIONS}

Significant correlations can be obtained between traffic levels and heavy metal concentrations. Hayany date palm cultivar was not affected by pollution contamination under conditions of this study.

\section{REFERENCES}

Baslar, S.; Y. Dogan; N. Yenil; S. Karagoz and H. Bag (2005). Trace Element Biomonitoring by leaves of Populus nigra L. from Western Anatolia, Turkey. J. En Viron Biol. 26: 665-668.

Black, C. A. (ed). (1965). Methods of Soil Analysis. Part 1 and 2. Soil Sci. Soc. Amer., Madison, USA.

Bircher, W.H. (1990). The date palm; A Boon for Mankind. Pp. 100; Cairo University Herbarium, Egypt.

Carter, M.R. (ed). (1993). Soil Sampling and Methods of Analysis. Candian Society of Soil Science, Lewis Publishers.

Divrikli, U.; D. Mendil; M. Tuzen; M. Soylak and L. Elci. (2006). Trace metal pollution from traffic in DenizliTurkey during dry season. Biomed Environ Sci. 19(4):254-61.

Dubios, M.; K.A. Gilles; J.K. Hamitton; P.A. Robers and F.Smith (1956). Colorimetric method for determination of sugars and related substances. Anal. Chem. 28(3): 350-356.

Evenhuis, B. (1976). Nitrogen determination. Dept. Agric. Res. Royal Tropical Inst., Amsterdam.

Evenhuis, B. and P.W. Dewaard (1980). Principles and practices in plant analysis. FAO soils Bull. 39(1): 152162.

Favretto, L.; G.P. Marletta and L.F. Gabrielli (1975). Pollution of vineyards by atmospheric lead. J. Sci. Food and Agric. 62(7): 987-922. 
Haggag, M.N. and A.M. El-Kobbia (1989). Effect of heavy metal pollution on leaf composition, fruit set and fruit quality of Washington Navel orange. Alex. J. Agric. Res. 34(1): 113-122.

Hoda, S.H. Aly, (2003). Nutritional status, yield, fruit quality and fruit nitrate, nitrite and some heavy metals contents of Zaghloul and Samany date palm cultivars in relation to fertilizing with different organic and inorganic nitrogen sources. Ph.D. Thesis, Fac. Agric. of Alex. Univ., Egypt.

Hose, G.C.; J.M. James and M.R. Gary (2002). Spider webs as environmental indicatiors. Environ. Pollut. 120: 725-733.

Iren, S. and Z.Y. Katiricioglu (1984). Studies on the effect of content of the soils, apple leaves, spurs and fruit from three experiment orchards. II. Leaves,spurs and fruit. Fruit, Sci.Rep. 15: 1, 35-41.

Klumpp, G.; C.M. Furlan; M. Domingos and A. Klumpp (2000). Response of stress indicators and growth parameters of Tibouchina pulchra Cogn. exposed to air and soil pollution near the industrial complex of Cubat?o , Brazil . Sci Total Envion. 31; 246(1): 79-91.

Kabata-Pendias, A. and H. Pendias (1992). Elements in soils and plants. $2^{\text {nd }}$ Ed. CRC Press, Florida, USA.

Kawamata, S. and H. Miyakoda (1973). Cadmium absorption by fruit trees. Agriculture and Horticulture, 48 (4):95-96.

Lagenwerff, J.V. and A.M. Specht (1970). Contamination of roadside soil and vegetation with cadmium, nichle, lead, and zinc. Environ. Sci. Yechno. 14: 583-586.

Li, J.T.; J.W. Qiu; X.W. Wang; Y. Zhong; C.Y. Lan and W.S. Shu. (2005). Cadmium contamination in orchard soils and fruit trees and its potential health risk in Guangzhou, China. University, Guangzhou 510275, PR China.

Manago, M.; K. Tanaka and C. Ogaki (1974). The effect of dust and of transportation along unpaved roads on Satsumas. Bull. Kanagawa Hort. Exp. Station 22:13-19. (Hort. Abst. Vol. 46, 3871).

Motto, H.L.; R.H. Daines; D.M. Chilko and C.K. Motto (1970). Lead in soils and plants: its relationship to traffic volume and proximity to highways. Enivron., Sci. Tecknol. 4:231-237.

Murphy and Riley (1962). A modified single solution method for the determination of phosphorus in natural waters. Anal. Chem. Acta 27: 31-36.

Pavan, M.A. and E.F.T. Bingham (1982). Toxicity of metals in plants. II. Nickle toxicity in coffee. Pesquisa
Agropecuaria Brasileira, 11(2): 323-328. (Soil and Fert. Vol. 45: 862).

Radwan, M. and Salama, A. 2006. Market basket survey for some heavy metals in Egyptian fruits and vegetables. Food and Chemical Toxicology 44: 1273-1278.

Rizk, S.A.Y. (1987). Studies on the effect of fertilization on date palm production. Ph.D. Thesis. Fac. Agric., Ain Shams Univ. , Egypt .

Rupp, D.; E. Ruhl and G. Allewedldt (1985). Cadmium toxicity in grapevines. Vitis 24(2): 88-96. (Soil and Fert. Vol. 48(11):1352).

Serra, J.A.; L. Perello and A. Maquieira (1981). Changes in the contents of $\mathrm{Fe}, \mathrm{Mn}, \mathrm{Cu}, \mathrm{Zn}, \mathrm{Ni}$ and $\mathrm{Pb}$ in Moscatel grapes in areas at different distances from sources of contamination. Agrochimica, 2 5(2): 156-161.

Shalaby, E.A.; I.H. El-Sokkary; S.H. El-Sayed and A.Y. Othman (1999). Cadmium and zinc bioaccumulation and excretion by earthworms: Aporrevtodea caliginosa and Aporrectodea rosea from industrially polluted soils of ElTabia. Alex. J. Agric. Res. 44(1): 335-350.

Snedecor, C.W. and W.G. Cochran (1990). Statistical methods $7^{\text {th }}$ ed. The Iowa State Univ. Press. Ames Iowa. USA. P. 593.

Swain, T. and W.E. Hillis. (1959). The phenolic constituents of Prunus domestica, 1. The quantitative analysis of phenolic constituents. J. Sci Food Agric., 10:63-68.

Wafaa, M. Amer and M.A. Zahran (1999). Palm Trees in Egypt. The International Conference on Date Palm, Assiut Univ. Center for Envir., studies, Egypt . P. 171189.

Ward, N.I.; R.D. Reeves and R.R. Brooks (1975). Lead in soil and vegetation along a New Zealand State highway with low traffic volume. Environ. Pollut. 9:243-351.

Yassoglou, N.; C. Kosmas; J. Asimakopolus and C. Kallianou (1987). Heavy metal contamination of roadside soils in greater Athens area. Environ. Pollut. 47:293-304.

Yetimoglu E.K.; O. Ercan and K. Tosyali (2007). Heavy metal contamination in street dusts of Istanbul (Pendik to Levent) E-5 highway. Ann. Chim. 97(3-4):227-35.

Ysart, G.; P. Miller; M. Croasdale; H. Crews; P. Robb; M. Baxter; C. L'Argy and N. Harrison (2000). Uk total diet study dietary exposures to aluminum, arsenic, cadmium, chromium, copper, lead, mercury, nickel, selenium, tin and zinc. Food Addti. Contam. 17(9): 775-786. 


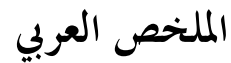

\section{تأثير تلوث البيئه على محتوى الأوراق وعقد الثمار وجودة ثمارنخيل البلح صنف الحيالن}

\author{
هدى سعد حسن على، عادل ابو السعود
}

نسبة عالية من السكريات الكليه بينما كانت أقلهم معنويا في لـــبـ

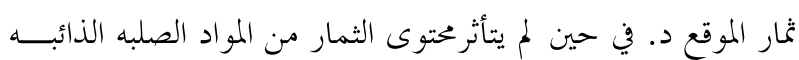

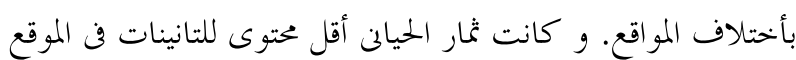
أ بالمقارنه بباقى المو اقع.

أما بالنسبة للمحتوى المعدني للثمار فقد زاد محتوى النيتروجين

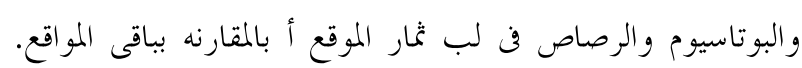

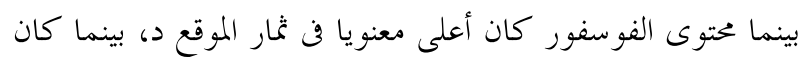

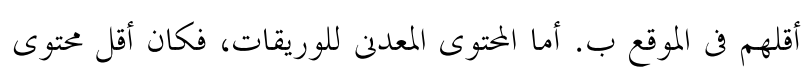

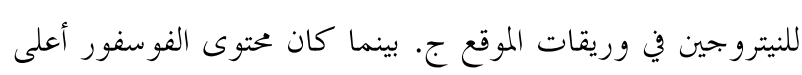

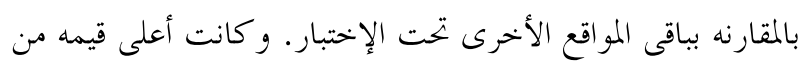

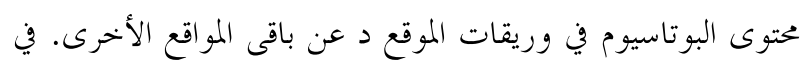

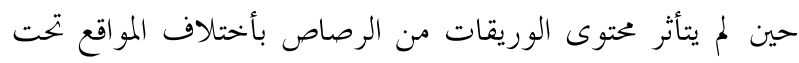

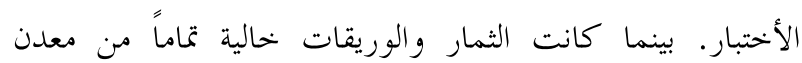

$$
\text { الكادميوم في كل المناطق تحت الدراسة. }
$$

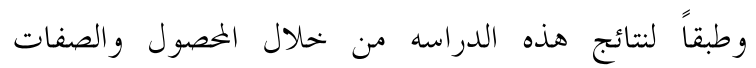

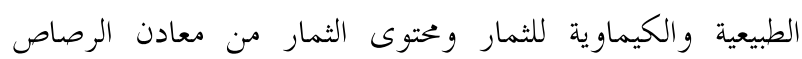

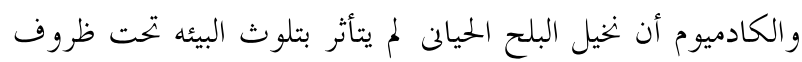
هذه الدراسة.

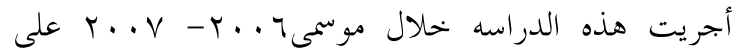
صنف الحيانن النامى في أربع مناطق مختلفه من حيث التلوث في التهن

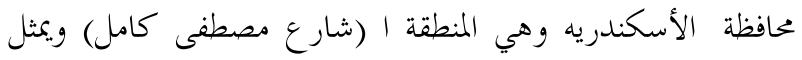
منطقه صناعيه وبها كثافه مروريه عاليه، المنطقة ب (طريق المطار) وهها كثافه مروريه عاليه والمنطقة ج (حديقة المنتزه) وهما كثافه نباتيه عاليه بالأضافه إلى أها منطقه مروريه والمنطقة د (الحديقه النباتيه

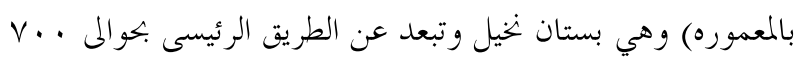

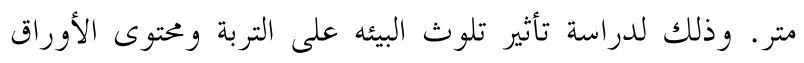

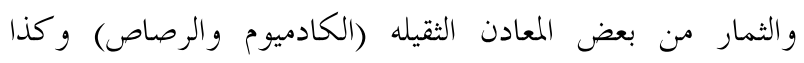

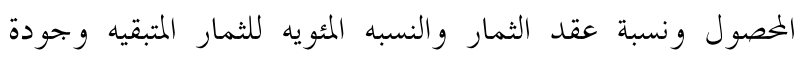

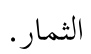
و كانت النتائج المتحصل عليها كما يلي:

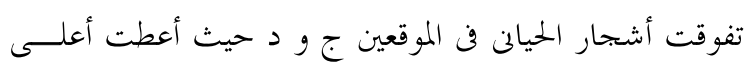

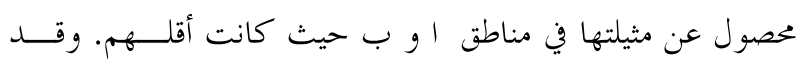

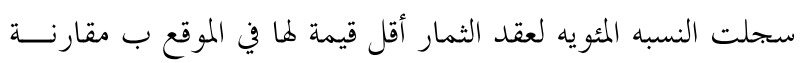

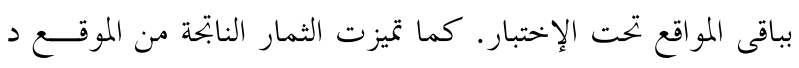

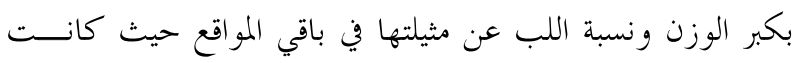

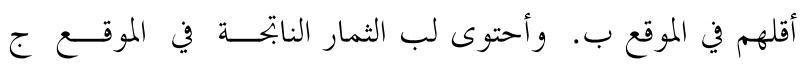

